\title{
Lack of Chinese Culture in College English Teaching and Its Countermeasures
}

\author{
Meijing LI \\ Foreign Language Department of Jilin Business and Technology College, \\ Changchun City, China, \\ Email:lihongbin1975@163.com
}

\begin{abstract}
Intercultural communication is a kind of interactive behavior. For a long time, college English teaching in China puts one-sided emphasis on the transmission of English culture, but ignores the teaching of Chinese native culture, leading to the learners' lack of Chinese traditional culture. What's worse, college students are unable to express and spread Chinese culture in English, which causes the phenomenon of "Chinese culture aphasia". This paper attempts to study the current situation and causes of "Chinese culture aphasia" in order to elaborate the countermeasures for the lack of Chinese native culture in college English teaching.
\end{abstract}

Keywords-college english teaching; intercultural communication; lack of Chinese culture

\section{INTRODUCTION}

It is generally believed in colleges that culture is important and necessary in English teaching, and it is necessary because it is hard to learn a foreign language well without paying attention to the connotation of the language. The lack of cultural awareness will directly affect the language learning and teaching. Culture teaching in English majored colleges has already been far from the primary stage. With the joint efforts of researchers and teachers in language teaching, cultural teaching in English majored colleges has achieved initial results, but college English teaching attaches more importance to target language culture and becomes unconscious of native culture, as a result, English culture is put in the highest flight of English teaching in colleges. In the process of cross-cultural communication, when it comes to English culture, Chinese students can make their argument with countless examples, but when it comes to Chinese native culture, a vast majority of Chinese students become wide-eyed and tongue-tied, no speaking of expressing it accurately in English. Undoubtedly, the phenomenon is due to the lack of Chinese native culture in the college English teaching.

\section{Causes of The Lack of Chinese Culture in College ENGLISH TEACHING}

\section{A. One-sided emphasis on English culture}

Language is the carrier of culture. Where there is language, there is culture. The inheritance and communication of culture should not be one-sided, instead, it must be bidirectional with the participation of both source language culture and target language culture. For a long time, College English teaching is inclined to the transmission of English culture and based on the introduction of the cultural knowledge, whose main purpose is to eliminate students' misunderstanding of western cultural differences in the process of cross-cultural communication, which inevitably causes the phenomenon of "Chinese culture aphasia". Professors in Tsinghua University Zhang Weimin and Zhu Hongmei conducted research in 2002 and thought that Chinese culture has been being obviously emphasized in college English teaching.

English-majored students in colleges know little about Chinese culture, even worse, some know nothing of Chinese native culture, no speaking that most Chinese students don't know how to correctly express Chinese native culture in English. It is bound to cause English-majored students in colleges to put western culture in the first flight in crosscultural communication process and thus ignore the exchange between Chinese and English culture. As a matter of fact, communication itself is bidirectional, which means absorption and transmission. (Widdowson, 1983). Excessive emphasis on western culture in teaching college English majors will cause the lack of Chinese culture (native cultural default) and lead to the "Chinese culture aphasia". ${ }^{[1]}$

English as a communication language, only on the basis of cultural fusion and influence in the implementation of the source language and target language culture can we truly achieve successful English language communication. Students should not turn a deaf ear to Chinese native culture at the same time of acquiring cultural knowledge in English countries. Both teachers and students also shoulder the historical mission that it is necessary to introduce the extensive and profound Chinese culture to English countries so as to make a balance between the target language culture and source language culture through language communication. The imbalance in the target and source language culture is the main cause of the lack of Chinese native culture in college English teaching.

\section{B. Lack of recognition to the international status of Chinese culture}

In recent years, with the development of China's economy and the rise of China's international status, 
Chinese culture attracts the attention of more and more foreigners and Chinese has become the foreign students' first choice of the second language in the western colleges. The popularity of Chinese marks that Chinese culture has suddenly appeared on the horizon of world stage in the process of cross-cultural communication and becomes a symbol of the internationalization of Chinese native culture. In traditional college English teaching, the lack of the internationalization of Chinese native culture leads directly to the difficulty to realize bilateral language communication, at the same time, it also causes the lack of Chinese native culture in the English teaching of college students.

\section{Teachers' ignorance of Chinese culture in college English teaching}

For a long time, many teachers in college English teaching blindly emphasizes the importance of the western culture and universities have also set relevant course, such as Background of Britain and America, Introduction to European Culture, British literature and American literature and so on, to introduce cultural background and knowledge of English countries from all aspects. Teachers pay more attention to students' grasp of the target language countries' culture and seldom introduce Chinese native culture, causing the deficiency of English majors' acquisition of Chinese native culture and one-sided communication in cross-cultural communication.

\section{Countermeasures to StREnGthen Chinese Cultural TEACHING IN ENGLISH-MAJORED COLLEGES}

\section{A. Strengthen the awareness of Chinese culture}

In English teaching, teachers are supposed to vigorously strengthen and promote Chinese culture essence, which is of great significance in English teaching. World civilizations' coexistence and cultural interaction mark the arrival of cultural globalization, as a matter of course, Chinese culture's internationalization is the important part of China's rising status in the world.

In English-majored colleges, Chinese culture-based English teaching class takes "Confucian culture", "harmony culture", "food culture", "kung fu" and "Chinese medicine" as the core of Chinese characteristics and puts these contents into English teaching in order to introduce rich and profound Chinese culture to the world and penetrate Chinese culture into the world culture. ${ }^{[2]}$ Chinese culture is not isolated out of the world culture, so, introducing Chinese culture into English teaching can expand and strengthen communication with people all over the world and implement the barrier-free cross-cultural communication in college English teaching.

\section{B. Improve the regional teaching of Chinese traditional culture}

English teachers should increase the teaching content of Chinese native culture to extend the students' knowledge of Chinese culture and Chinese cultural heritage. The most efficient way is to strengthen the teaching of Chinese native culture. English-majored teachers, based on the traditional culture, should gradually implement English teaching of Chinese native culture.

\section{Cultivate students' recognition of Chinese culture}

The purpose of learning English not only lies in listening, speaking, reading, writing and translating skills, but also reflects in spreading Chinese culture to the world in English, so cultivating learners' intercultural communicative competence is the main goal of English teaching. With increasingly globalization of the world's economic and cultural exchanges, English learners in colleges and universities should clear the purpose of learning English, improve their cross-cultural communication consciousness and equally view on the status and role of the English and native language. They should enhance the recognition of Chinese culture, constantly improve their ability of crosscultural communication, and promote two-way communication and understanding between Chinese and western culture.

\section{Improve teachers' appreciation of Chinese culture}

Students are the main body of teaching and teachers are the leader of teaching. Therefore, teacher's appreciation of Chinese native culture can determine the accomplishment of culture-based English teaching. So, in order to strengthen the Chinese native culture teaching, teachers should improve their ability of Chinese native culture accomplishment and acquisition. Also, they should pay attention to the screening of culture teaching content in daily teaching, and especially focus on the improvement of students' ability to communicate Chinese native culture in English, so as to achieve successful interactive crosscultural communication. If teachers can consciously carry on a comparative teaching in Chinese and western culture, it will be effective to improve students' skills to express Chinese culture in English and understand cultural knowledge of English countries.

In addition, teachers can make use of cooperative learning method and let the student study autonomously in the form of group through the network, TV, film, radio and so on, and then strengthen the standard of Chinese native culture by oral presentation, composition or small discussion, training and examining students' ability in English expression of Chinese culture. In the test section, in addition to test the students' language foundation, some contents related to Chinese culture and foreign cultural differences should be appropriately added, such as: English verbal or written communication of Chinese cultural characteristics, Chinese culture-based English composition, or thesis to compare Chinese and foreign culture difference, which not only tests the students' mastery of Chinese native culture but also cures "aphasia phenomenon" in oral communication. ${ }^{[3]}$

\section{E. Reform of curriculum}

Most colleges and universities haven't set courses of Chinese culture for English majors, which is because universities haven't been aware of the importance of 
Chinese traditional culture in learning English. Since December 2013, CET 4 and 6 has been reforming the test from the original sentence translation into paragraph translation, and more importantly, the content of the paragraph translation completely is about Chinese traditional culture, such as paper cutting, the Spring Festival, tea, etc. The college entrance examination also tends to reduce the proportion of English and increase the total score of Chinese in order to improve and strengthen students' awareness of Chinese culture. ${ }^{[4]}$ Thus, it can be seen that the ministry of education is to strengthen the study of Chinese traditional culture, therefore, college English curriculum can add the contrast between Chinese and western culture. English major also can set English courses like Chinese philosophy, history, literature, art and customs. Through these courses, students are able to make a simple introduction of traditional Chinese culture in English, which is also to improve the status of Chinese culture.

\section{CONCLUSION}

To sum up, the lack of Chinese culture in the college English teaching in China is a refraction of the disadvantages of college English teaching. This phenomenon in English teaching in colleges and universities should not be ignored, which still needs further analysis and exploration so as to get rid of the plight of "aphasia", achieving the cross-cultural communication of languages.

\section{REFERENCE}

[1] $\mathrm{Hu}$ Wenzhong. Introduction to Cross-cultural Communication[M] Beijing: Foreign Language Teaching and Research Press,1999.

[2] Zhang Weimin, Zhu Hongmei. Chinese culture in college English teaching $[\mathrm{J}]$. Tsinghua Journal of Education,2002(1).

[3] Widdowsort, H.G. Learning Purpose and Language Use[M]. Oxford Oxford University Press, 1983.

[4] Wang Chuanli. Analysis of "Chinese culture aphasia" in college English teaching[J]. Journal of Teaching and Management,2011(10) 